\title{
Carboniferous biostratigraphy of Sonora: a review
}

\author{
Pilar Navas-Parejo \\ Estación Regional del Noroeste, Instituto de Geología, Universidad Nacional Autónoma de México, \\ Blvd. Luis Donaldo Colosio s/n, C.P. 83000, Hermosillo, Sonora, Mexico. \\ pilarnpg@geologia.unam.mx
}

\begin{abstract}
A thorough review of the available literature regarding biostratigraphic studies on the Carboniferous sedimentary rocks of Sonora, northwestern Mexico, is presented here. Most frequently reported fossils are marine invertebrates as well as protozoans and vertebrate remains. Most abundant groups are corals, both solitary and colonial, fusulinids and other foraminifera, conodonts, and brachiopods. Less commonly described groups are crinoids, algae, bryozoans, and radiolarians. This revision evidences the high paleobiodiversity and potential research interest of the Carboniferous geological record of Sonora. Although published studies including paleontological information greatly lack detailed specific taxonomic determinations or biostratigraphic analyses, the presence of all Mississippian and Pennsylvanian stages can be inferred. Regional stratigraphic gaps and hiatuses, however, are difficult to determine because of this scarcity of precise datings. Current lithostratigraphic units defined formally or informally are also reviewed.
\end{abstract}

Key words: Mississippian; Pennsylvanian; stratigraphy; paleontology; southwestern Laurentia; Sonora; Mexico.

\section{RESUMEN}

En este trabajo se presenta una exhaustiva revisión de la literatura disponible sobre la bioestratigrafía de las rocas sedimentarias del Carbonífero de Sonora, noroeste de México. Los fósiles reportados más frecuentemente corresponden con invertebrados marinos, así como protozoos y restos de vertebrados. Los grupos más abundantes son los corales, tanto solitarios como coloniales, fusulínidos y otros foraminíferos, conodontos y braquiópodos. En menor medida también se han descrito crinoides, algas, briozoarios y radiolarios. Esta revisión pone de manifiesto la gran paleobiodiversidad y el interés potencial de investigación del registro geológico del Carbonífero de Sonora. Aunque los estudios publicados que incluyen información paleontológica mayormente carecen de determinaciones taxonómicas a nivel específico o de análisis bioestratigráficos, se puede deducir la presencia de todos los pisos del Misisípico y del Pensilvánico. Sin embargo, lagunas e hiatos estratigráficos de carácter regional son difíciles de determinar debido a esta escasez de dataciones precisas. También se revisaron las unidades litoestratigráficas actualmente usadas, definidas tanto formal como informalmente.

Palabras clave: Misisípico; Pensilvánico; estratigrafía; paleontología; Laurencia suroccidental; Sonora; México.

\section{INTRODUCTION}

Carboniferous outcrops in Sonora were firstly described by Imlay (1939) and Dunbar (1939) in strata related to the Laurentian craton in the northeastern part of the state (Figures 1, 2, locs. C8, C9). Shortly after, Cooper and Arellano (1946) studied the Paleozoic of the Caborca region, northwestern Sonora, and described Mississippian brachiopods and corals from the Rancho El Bízani area (Figures 1, 2, loc. S1, sometimes misspelled as El Bisani).

Since then, a considerable number of studies, both research articles and theses, have been made based on paleontological material from Sonoran Carboniferous rocks. The most important biostratigraphic contribution to the Carboniferous of Sonora is, by far, the work of Peiffer-Rangin (1988), who visited the state during the 70's, studied a number of localities, collected and described a great number of invertebrates and interpreted her results in a paleogeographical setting. Unfortunately, her study remains unpublished and only an incomplete manuscript is currently available.

Important contributions to the knowledge of the Carboniferous of Sonora have also been made by geologists of the United States Geological Survey, especially by John H. Stewart and Forrest G. Poole, who visited the state many times since the 70's and have published a considerable number of papers and field-trip guides. Stewart and Poole (2002) prepared a thorough inventory of Paleozoic localities of Sonora, including also some of their unpublished or preliminary results. Most part of this inventory along with new data on some localities, and spread to adjacent areas both in Mexico and the United States, were included in the most recent synthesis of the Paleozoic of Sonora, published by Poole et al. (2005).

A number of professional, master and Ph.D. theses, mostly written during the last decades of the last century by students from the Universidad de Sonora and other North American universities, dealt 
with different aspects of the geology of the Paleozoic and, especially, with the Carboniferous rocks of Sonora.

All these studies expose the richness of the Sonoran Carboniferous paleontological patrimony and the completeness of its geological record. Unfortunately, a number of these works remain unpublished for different reasons or they are part of the bibliographic heritage in their respective universities without digital record. The aim of this work is to summarize the current knowledge of the Carboniferous biostratigraphy of Sonora, focusing on the best-constrained ages obtained until now and the most important outcrops.

\section{LATE PALEOZOIC ROCKS OF SONORA}

Permo-Carboniferous rocks are most common in the Mexican Paleozoic sequences according to the current knowledge, being the most abundant those to the northwestern part of the country (Sánchez-Zavala et al., 1999). Paleozoic rocks of Sonora testify for three depositional paleoenvironments (Figure 1): two separate shallow- water successions that range from the Cambrian to the Permian, and a southern succession that correspond to an Ordovician to Pennsylvanian deep-water basin (e.g., Peiffer-Rangin, 1988; Stewart et al., 1990; Poole et al., 2005). Paleozoic rocks cropping out to the north of the state (Figure 2) correspond to the southern extension of the Laurentian craton, which broadly crops out in the southern United States (e.g., Poole and Sandberg, 1977; Cocks and Torsvik, 2011). These shallow marine rocks are related to a carbonate platform that was located in a tropical position during the Mississippian and has been referred to as the Redwall-Pedregosa shelf (e.g., Gutschick and Sandberg, 1983). Paleozoic rocks that appear in the center and northwestern part of the state have been considered to represent the southern Laurentian continental shelf (Figures 1, 2, 3), formerly referred to as the Cordilleran miogeoclinal (e.g., Peiffer-Rangin, 1988; Stewart, 1988; Stewart et al., 1990). This continental shelf was apparently continuous from the southwestern United States to northwestern Mexico during the Paleozoic, until no later than the Devonian period. Devonian and Mississippian faunas found in the Sonoran continental shelf are similar to those reported for southern and eastern United States and northern Mexico,

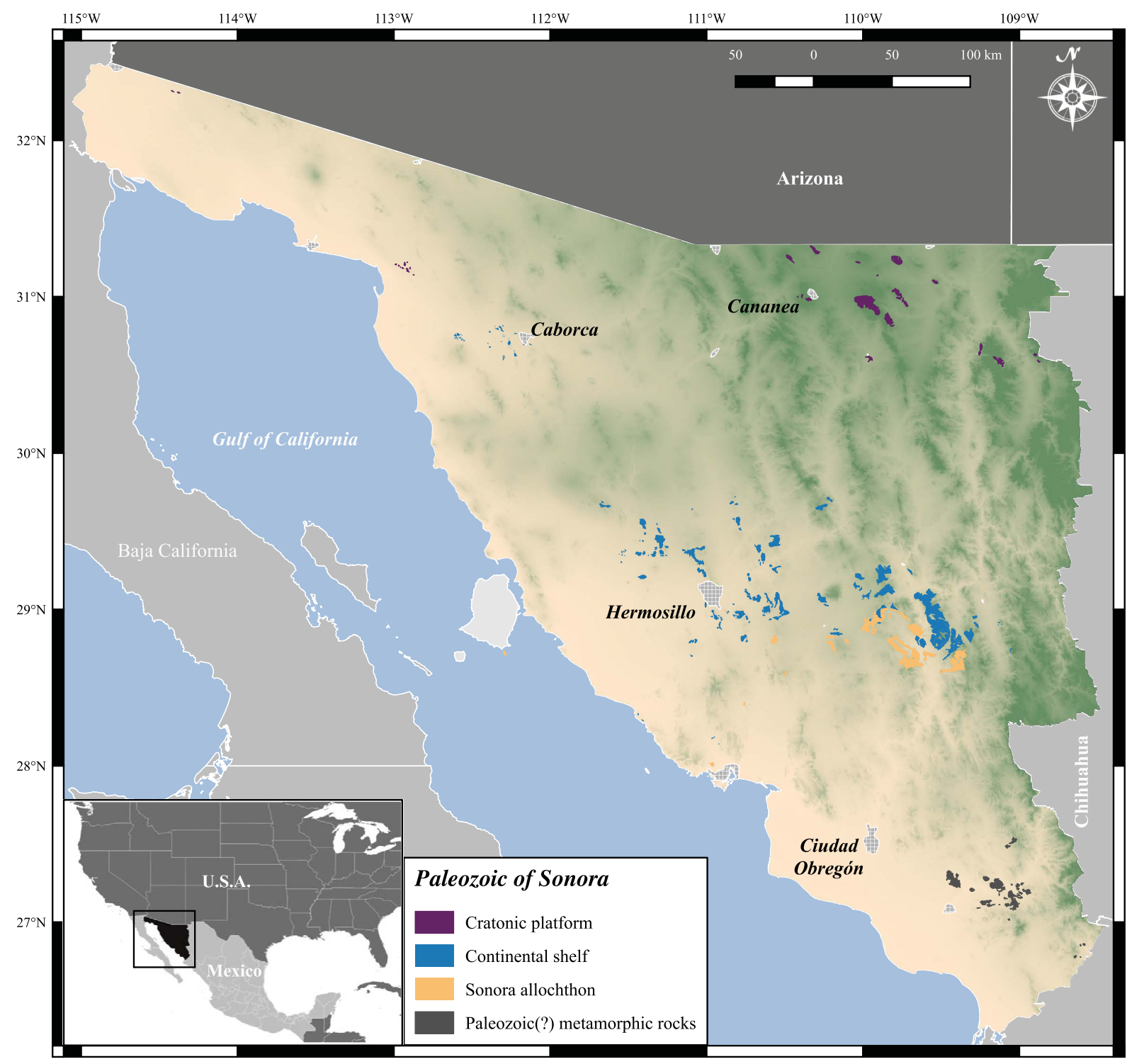

Figure 1. Paleozoic outcrops in Sonora, NW Mexico (compiled from 1:50,000 maps of the Servicio Geológico Mexicano and González-León et al., 2006). 
but different from those from the western United States (Poole et al., 2005; Boucot et al., 2008; Navas-Parejo et al., in press). Ocean-basin rocks, previously referred to as eugeoclinal or eugeosynclinal rocks, and currently known as the Sonora allochthon (Poole and Madrid, 1988; Stewart et al., 1990, p. 187; Poole et al., 2005), crop out in central Sonora (Figures 1,3). This succession typically represents the OuachitaMarathon orogenic belt and it is now accepted as its westernmost segment (e.g., Peiffer-Rangin, 1988; Poole et al., 2005). The Sonora allochthon is divided into two successions: pre mid-Mississippian preorogenic strata, and a mid-Mississippian-Late Pennsylvanian synorogenic succession (Poole et al., 2005, 2008). Correlation of the Sonora allochthon with other orogenic segments that currently crop out in Texas (Marathon Region), Oklahoma (Black Knob Ridge), and Arkansas (Ouachita Mountains) is based both on lithology and fossil associations (Peiffer-Rangin, 1979, 1988; Noll et al., 1984; Poole et al., 2005; Boucot et al., 2008). Upper Paleozoic rocks from northern Baja California have been correlated also with the Sonora allochthon (Gastil, 1993; Poole et al., 2005; Navas-Parejo et al., 2018). A Gondwanan affinity has been inferred for Famennian conodont faunas found in the Sonora allochthon, whereas Laurentian forms have been described in the continental carbonate-shelf (Navas-Parejo et al., 2016a, 2016b). In addition, the Mina México flysch (Hewett, 1978; Schmidt, 1978) was deposited on a middle Permian (Guadalupian) foredeep related to the collision of Gondwana and Laurentia, and it currently appears concordantly and transitionally over the Laurentian shelf, Permian succession (La Cueva Limestone), and overthrusted by the Sonora allochthon in central Sonora (Stevens et al., 2014).

\section{CARBONIFEROUS STRATIGRAPHY OF SONORA}

Carboniferous outcrops are most abundant in the exposed Paleozoic rocks of Sonora, and most of them correspond to continentalshelf rocks (Figure 1). Mississippian and/or Pennsylvanian localities reported in the literature are indicated in Figures 2 and 3.

Carboniferous continental-shelf rocks are mainly made up of very fossiliferous, shallow-water limestones, mostly crinoid-grainstone limestones, regionally known as encrinites (Ausich, 1997), which form cliffs and significant reliefs. Some of the best-known and most studied areas are the Sierra Agua Verde (loc. S14), Sierra Santa Teresa (loc. S3), Cerro Cobachi (loc. S9), Rancho Las Norias (loc. S6) and Rancho El Bízani (loc. S1). This sequence is, however, the less organized stratigraphically and mapping units or formations have been defined only locally at each outcrop or locality (Figure 4). The area where the Carboniferous part of the continental shelf sequence is likely most complete is the Sierra Agua Verde. There, several geological and biostratigraphic studies have been made, among which the broadest are those of Ochoa-Granillo and Sosa León (1993) and Stewart et al. (1999). Ochoa-Granillo and Sosa-León (1993) grouped the Mississippian rocks in the Santiago formation, after the Cerro Santiago, where the type section appears, and the Pennsylvanian limestones in the La Joya formation, being the type area located at the Arroyo La Joya (Figure 4). Recent works, however, advised against the use of this nomenclature. On one hand, as Reyes-Montoya (2017) pointed out, the Santiago formation also corresponds to a Mississippian stratigraphic formation previously defined in southern Oaxaquia, Mexico (Pantoja-Alor, 1970). On the other hand, the lower part of the type section of the La Joya formation has been recently dated as Middle-Late Mississippian (Navas-Parejo et al., in press); a revision on the age and distribution of the La Joya formation was, therefore, recommended. Stewart et al. (1999) divided Paleozoic rocks of the Sierra Agua Verde in a series of cartographic units, including Upper Devonian and Mississippian rocks in their MDc map unit and the Pennsylvanian strata in the Pc map unit.

Carboniferous rocks in northeast Sonora (Figure 5) have been traditionally correlated to equivalent stratigraphic formations cropping out in southern Arizona, which were firstly defined by Ransome (1904) (e.g., Taliaferro, 1933; Imlay, 1939; Gómez-Tagle, 1967). Mississippian limestones are grouped there in the Escabrosa Formation, and the Pennsylvanian carbonates are included in the Horquilla Formation. Most significant areas in northeastern Sonora are the Sierra El Tule (loc. C2) and the Sierra Los Ajos (loc. C6). The most important eastern outcrops of this Carboniferous facies in Sonora correspond to the Sierra de Teras, also known as the El Tigre mine area (loc. C8). These Carboniferous limestones, together with the Permian rocks, were included in the informal El Tigre formation (Imlay, 1939). Some authors recommended, however, that the El Tigre formation should be used only for Permian limestones (Hewett, 1978; Schmidt, 1978; Noll 1981). Later, Poole et al. (2005) and Stevens et al. (2014) proposed to

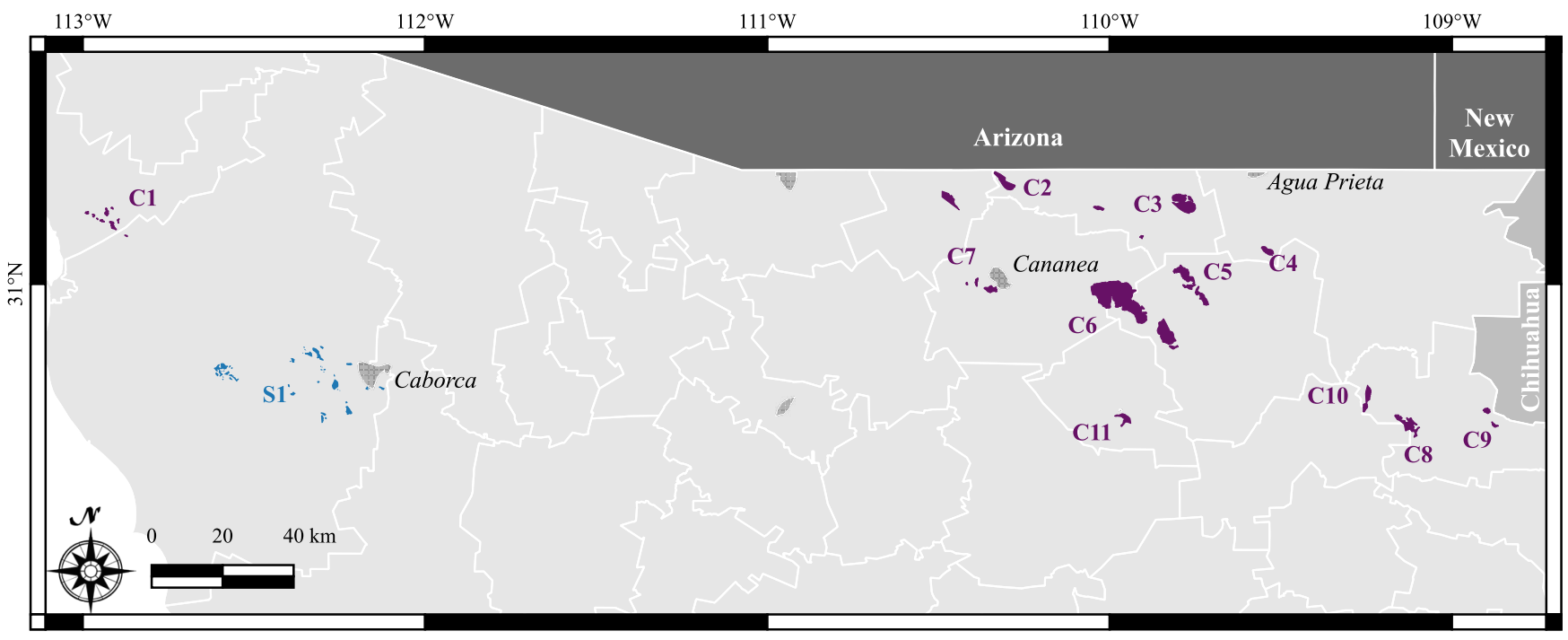

Figure 2. Paleozoic outcrops in northern Sonora, NW Mexico (compiled from 1:50,000 maps of the Servicio Geológico Mexicano and González-León et al., 2006). Numbers indicate Carboniferous localities included in Figures 4 and 5. Color code as in Figure 1. 


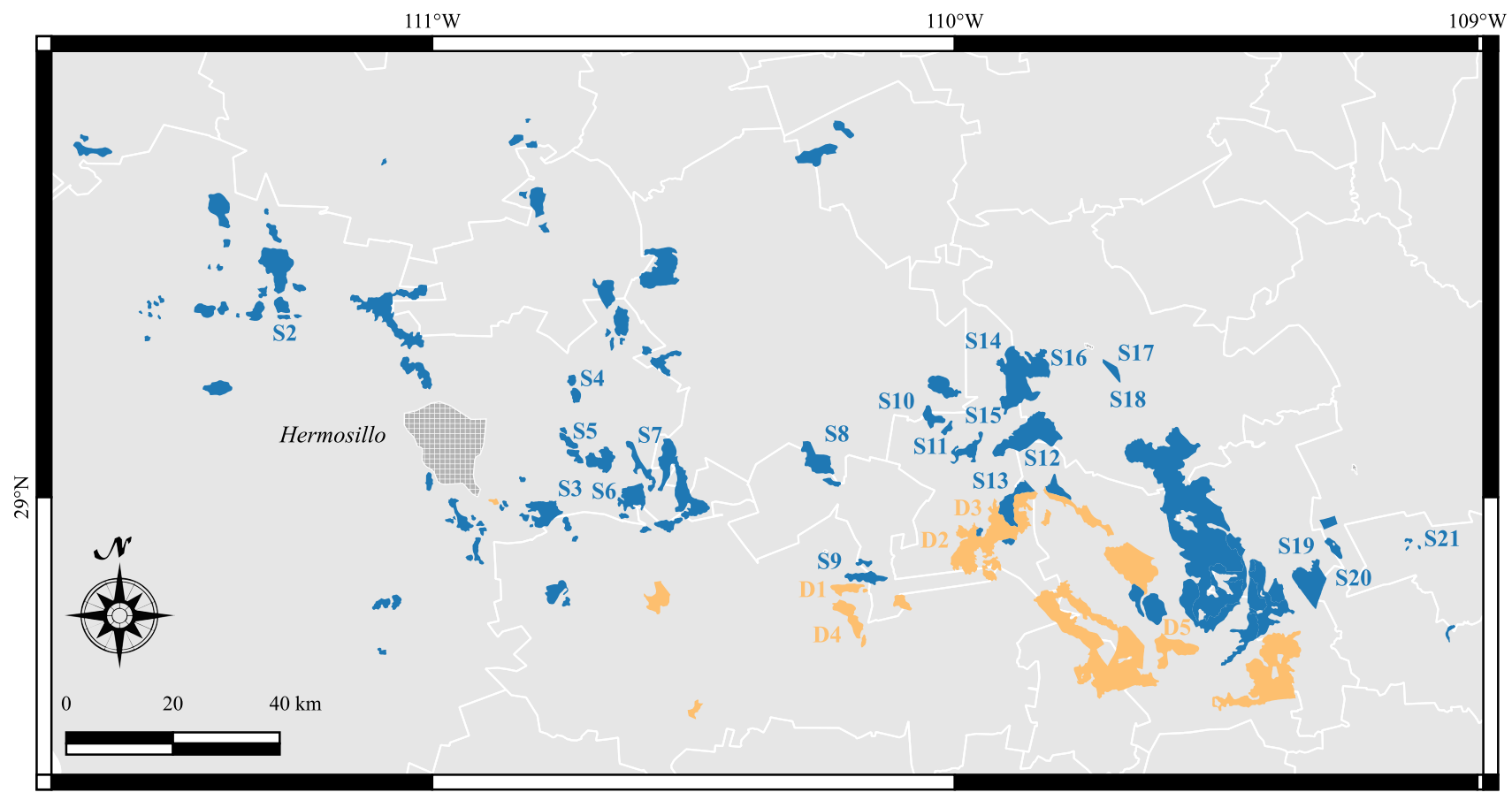

Figure 3. Paleozoic outcrops in central Sonora, NW Mexico (compiled from 1:50,000 maps of the Servicio Geológico Mexicano and González-León et al., 2006). Numbers indicate Carboniferous localities included in Figures 4 and 5. Color code as in Figure 1.

abandon the term. Palafox (2011) studied the mid and late Paleozoic continental shelf rocks from central Sonora and applied Ransome's stratigraphic nomenclature also to that strata.

Carboniferous rocks of the Sonora allochthon have been thoroughly studied by Poole and collaborators (e.g., Poole and Madrid, 1988; Poole and Amaya-Martínez, 2000; Poole et al., 2005, 2008; Stevens et al., 2014). They include the uppermost part of the Los Pozos Formation, the Lower Mississippian Cerro Tasajo Limestone, the Middle Mississippian Los Chinos Conglomerate, and the Upper Mississippian-Upper Pennsylvanian Rancho Nuevo Formation (Figure 5). The type locality of the Sonora allochthon is the Mina de Barita area (loc. D2), although formations defined there can be also found in other regions as the Cerro Cobachi area (loc. D1). Previous studies made in the Cerro Cobachi area are those of Noll (1981) and Ketner and Noll (1987). They included the Ordovician to Middle Mississippian part of the deep-water allochthonous sequence in the Guayacán Group, and the Pennsylvanian in the Vuelta Colorada Formation. The Cerro Cobachi area is, in addition, one of the few areas where both the Sonora allochthon and continental shelf rocks crop out, although the contact is practically covered by recent sediments. Also at the Cerro Cobachi, Noll (1981) and Ketner and Noll (1987) grouped Upper Mississippian and Pennsylvanian shallow-water rocks in the Picacho Colorado Formation (Figure 4).

\section{CARBONIFEROUS BIOSTRATIGRAPHY}

Except for conodonts and some fish remains, Carboniferous fossils found in Sonora are all invertebrates. Most frequently reported fossil groups are fusulinids and other foraminifera, corals, both solitary and colonial, brachiopods, as well as conodonts. Less commonly described are algae, radiolarians, bryozoans and crinoids. A comprehensive analysis of faunal content, geographical distribution, and biostratigraphic ranges is however, hindered by the lack of specific taxonomic determinations, systematic paleontology, and fossil illustrations in most published studies including fossils. In many cases, not even the exact location of the sample is given.

A composite biostratigraphic record shows that, apparently, all the Carboniferous stages are present in Sonora. This statement, however, needs to be confirmed after more detailed studies in the different areas, as local hiatuses do exist. In addition, in some cases, taxonomic determinations have been made only at generic level, hence biostratigraphic ages are not well constrained.

\section{Mississippian}

Mississippian fossils have been described in all three depositional paleoenvironments, although more frequently in the shallowmarine facies. Until now, in the Sonora allochthon, distinctive Early Mississippian fossils have been reported only at the Cerro Cobachi (Figures 3, 6, loc. D1), although neither fossil group nor association was included (Ketner and Noll, 1987). Poole et al. (2005) reported the presence of Early Mississippian conodonts in the Cerro Tasajo Limestone, defined in the Sonora allochthon cropping out at the Mina de Barita area. They indicated, however, neither where samples were collected nor the conodont association. Certain Middle Mississippian fossils in the Sonora allochthon were reported only in the Sierra El Aliso (Figures 3, 5, loc. D5) by Bartolini (1988) and Bartolini et al. (1989).

Ages on most rocks of the cratonic-platform sequence have been identified by facies comparison and lithological correlations with the well-known Mississippian Escabrosa Formation defined in Arizona (e.g., Ransome, 1904; Taliaferro, 1933; Imlay, 1939; Gómez-Tagle, 1967). Blodgett et al. (2002) and Page et al. (2010) reported the presence of Mississippian corals, bryozoans, brachiopods and crinoids, without specifying species or detailed biostratigraphic ranges, from the Sierra Los Ajos area (Figures 2, 5, loc. C6).

Fossil identifications allowing accurate datings are summarized in the following sections. Other mentions of Mississippian fossils without specific biostratigraphic ranges are summarized in Figures 7 and 5. 


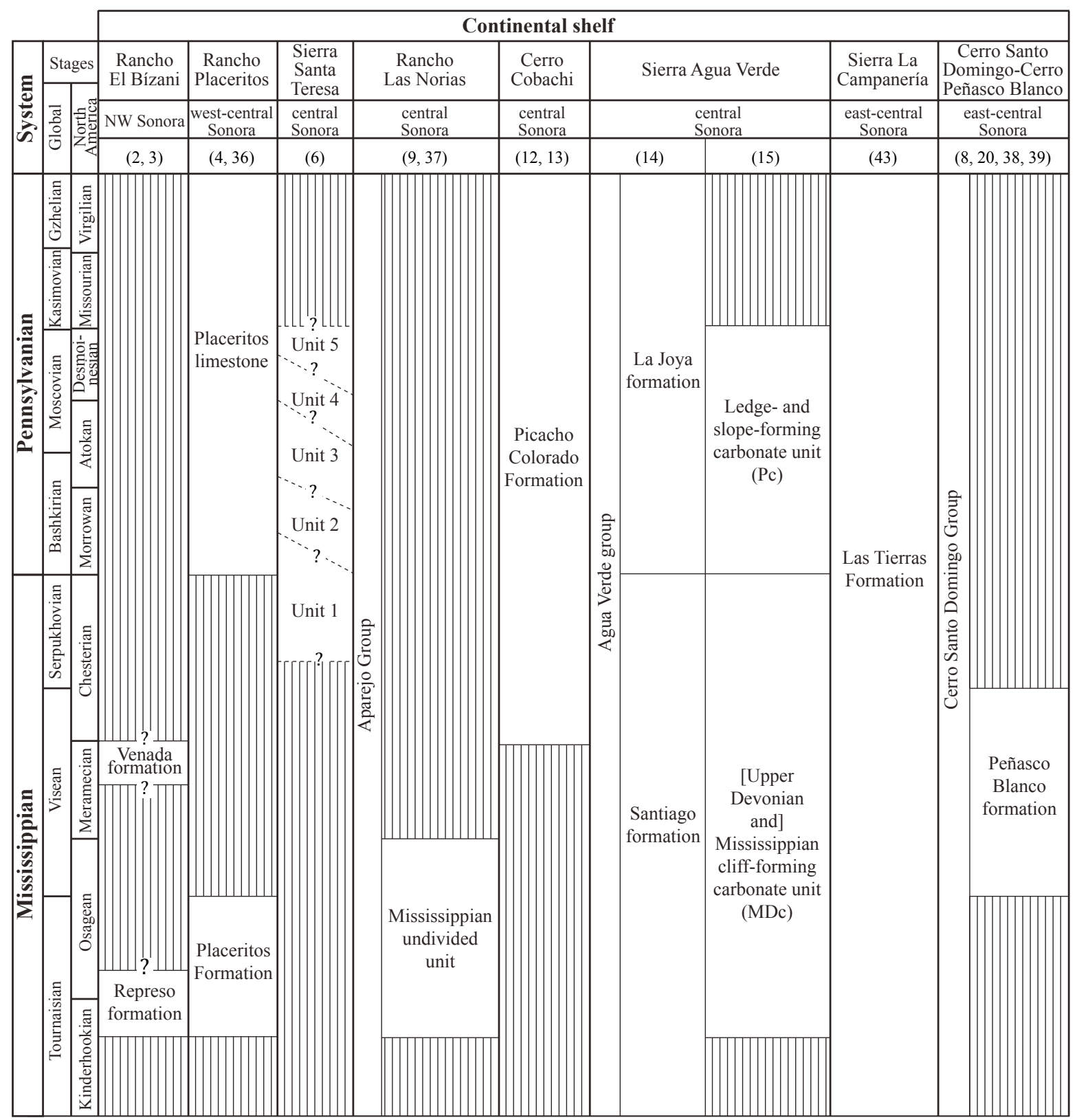

Figure 4. Lithostratigraphic units reported for the Carboniferous continental shelf of Sonora. Compiled from multiple sources; numbers in parentheses indicate references (see Table 1).

\section{Lower Mississippian}

Continental shelf. The oldest well-constrained Mississippian age in the continental shelf strata is Kinderhookian. One fossil association came from a sample collected by Vega-Granillo (1996) in central Sonora and studied by Charles A. Sandberg (fide Stewart and Poole, 2002), who accurately dated a middle Kinderhookian age (S. sandbergi Zone or younger) by means of conodonts (Figures 3, 7, loc. S8). At the Rancho Las Norias (Figures 3, 7, loc. S6), Page et al. (2003) also reported middle Kinderhookian ( $S$. sandbergi Zone) conodont associations, in a succession that ranges up to within the Osagean (Lower texanus Zone).

At Rancho Placeritos (Figures 3, 7, loc. S2), Poole et al. (2003) dated a late Early Mississippian succession as from the upper Kinderhookian (S. isostichia-upper S. crenulata Zone) to the middle Osagean (anchoralis-latus Zone) by means of conodonts. Conodonts, foraminifers, and algae reported by Stewart et al. (1999) and Palafox (2011) at the Sierra Agua Verde (Figures 3, 7, loc. S14) allowed identifying Lower Mississippian strata in the area, being the late Kinderhookian (S. isosticha-Upper S. crenulata Zone) the oldest age reported. Moreover, conodont associations described by Stewart et al. (1999) proved the presence of all conodont biozones from the S. isosticha-Upper S. crenulata Zone to the Sc. anchoralis-D. latus Zone.

The Kinderhookian-Osagean boundary has been identified by means of brachiopods, corals, and conodonts in the Rancho El Bízani area (Figures 2, 7, loc. S1) by Cooper and Arellano (1946), Easton et al. (1958), and Brunner (1976), respectively.

Peiffer-Rangin (1988) described Osagean-Meramecian foraminifers and corals at the Puerto El Orégano (Figures 3, 7, loc. S7), and Osagean brachiopods, bryozoans, and corals at the Cerro San Pedro (Figures 3, 7, loc. S17). 


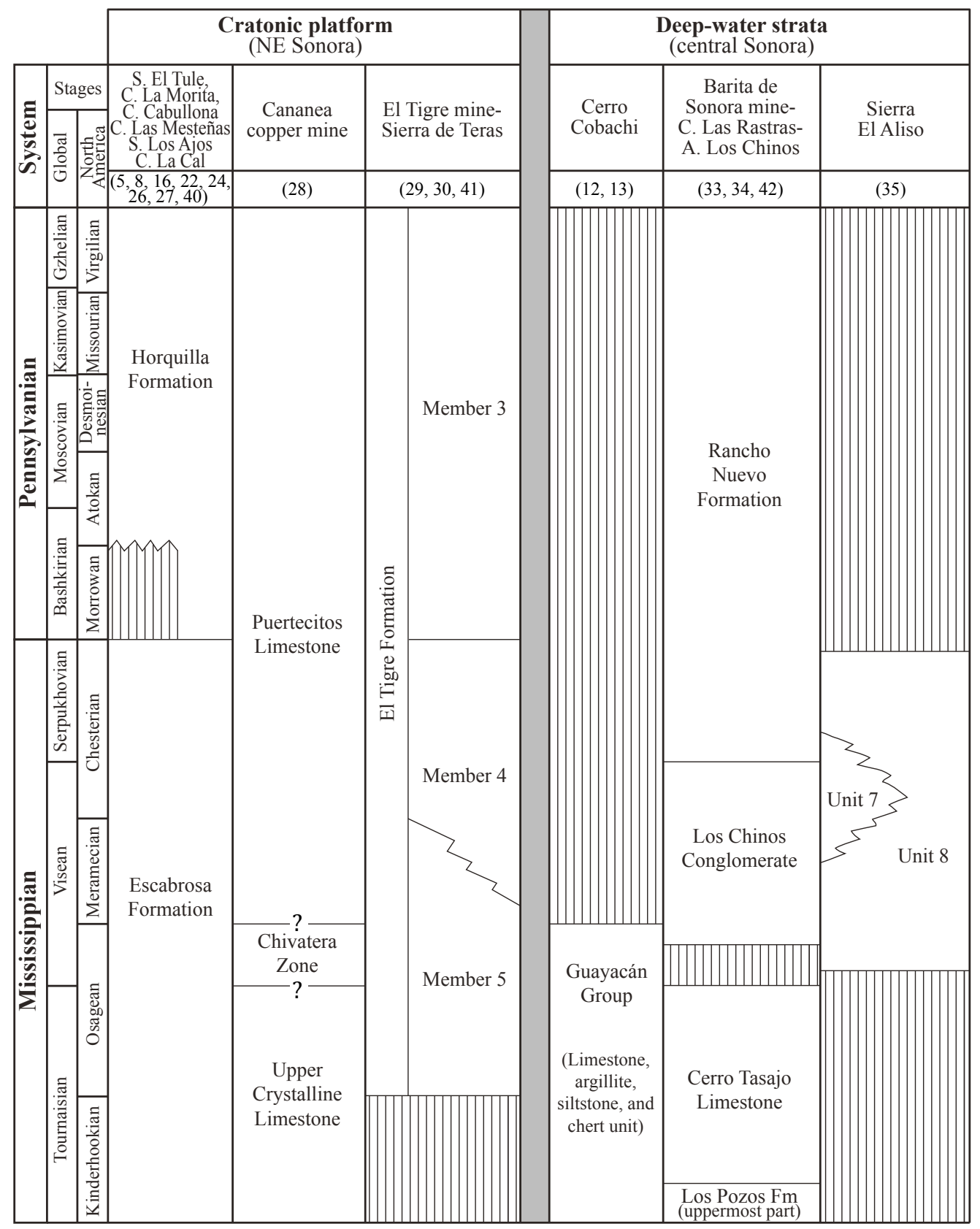

Figure 5. Lithostratigraphic units reported for the Carboniferous cratonic platform and deep-water rocks of Sonora. Compiled from multiple sources; numbers in parentheses indicate references (see Table 1).

Other Early Mississippian fossils of Sonora include foraminifera studied by Palafox (2011) at the Cerro El Yugo (Figures 3, 7, loc. S20), as well as corals and conodonts in the El Real Viejo (Figures 3, 7, loc. S20) and the Cerro Peñasco Blanco (Figures 3, 7, loc. S22), reported by Stewart and Poole (2002).

Cratonic platform. The best-known Early Mississippian locality in northeastern Sonora is the Sierra El Tule (Figures 2, 6, loc. C2). González-León (1986) studied a section in the Cerro Coloso (Sierra El Tule), where Mississippian rocks form cliffs and contain abundant crinoids (encrinites), corals and brachiopods, with minor presence of echinoderms. In the lower part of the section he found the corals Stelchophyllum microstylum and Sychnoelasma sp., which indicate a Kinderhookian-Osagean age. Among the studied sections by Peiffer-
Rangin (1988) in the Sierra El Tule, the Cerro Coloso includes diverse fauna associations, the Kinderhookian-Osagean coral Sychnoelasma konincki being especially noteworthy. Peiffer-Rangin (1988) also described Early Mississippian corals as Sychnoelasma konincki and Michelinia expansa from the Cerro Agua Dulce, at the north end of the Sierra El Tule. Palafox (2011) and Buitrón-Sánchez et al. (2012) reported the presence of Tournaisian (Kinderhookian-lower Osagean) benthic foraminifera, including Earlandia minor, Tuberendothyra safonovae, and Inflatoendotothyra parainflata, also at the Sierra El Tule, although they did not precisely locate the section.

According to Peiffer-Rangin (1988), the most complete Paleozoic section from northeastern Sonora is located in the Cerros Las Mesteñas (Figures 2, 6, loc. C5). There, she identified at least the lower part of 
Table 1. List of data sources used to construct Figures 4, 5, 6, and 7.

\begin{tabular}{ll}
\hline Number & Data source \\
\hline$(1)$ & Cooper and Arellano (1946) \\
$(2)$ & Easton et al. (1958) \\
$(3)$ & Brunner (1976) \\
$(4)$ & Poole et al. (2003) \\
$(5)$ & Peiffer-Rangin (1988) \\
$(6)$ & Stewart et al. (1997) \\
$(7)$ & Rodríguez-Castañeda (1981) \\
$(8)$ & Stewart and Poole (2002), and/or Poole et al. (2005) \\
$(9)$ & Page et al. (2003) \\
$(10)$ & Casarrubias (2015) \\
$(11)$ & Vega-Granillo (1996) \\
$(12)$ & Noll (1981) \\
$(13)$ & Ketner and Noll (1987) \\
$(14)$ & Ochoa-Granillo and Sosa-León (1993) \\
$(15)$ & Stewart et al. (1999) \\
$(16)$ & Palafox (2011) \\
$(17)$ & Buitrón-Sánchez et al. (2007), and Almazán-Vázquez et al. (2007) \\
$(18)$ & Navas-Parejo et al. (in press) \\
$(19)$ & Minjarez et al. (1985) \\
$(20)$ & Palafox et al. (1984) \\
$(21)$ & Pérez-Ramos (1992) \\
$(22)$ & González-León (1986) \\
$(23)$ & Buitrón-Sánchez et al. (2012) \\
$(24)$ & Viveros-Martínez (1965) \\
$(25)$ & Villanueva-Olea et al. (2016) \\
$(26)$ & Bridges (1970), Aponte-Barrera (1974), and López-Ramos (1982) \\
$(27)$ & Blodgett et al. (2002), and Page et al. (2010) \\
$(28)$ & Mulchay and Velasco (1954) \\
$(29)$ & Imlay (1939) \\
$(30)$ & Holcomb (1979), Devery (1979) \\
$(31)$ & Dunbar (1939) \\
$(32)$ & Poole et al. (1983) \\
$(33)$ & Poole and Amaya-Martínez (2000) \\
$(34)$ & Stevens et al. 2014 \\
$(35)$ & Bartolini (1988), Bartolini et al. (1989) \\
$(36)$ & Avila (1987) \\
$(37)$ & Vega-Granillo and Araux (1987) \\
$(38)$ & Palafox and Martínez (1985) \\
$(39)$ & Minjárez and Torres (1987) \\
$(40)$ & Gómez-Tagle (1967) \\
\hline & Poole and Madrid (1988) \\
\hline &
\end{tabular}

the Escabrosa Limestone by means of Lower Mississippian corals and brachiopods.

In the Cananea mine area (Figures 2, 6, loc. C7), Mulchay and Velasco (1954) found brachiopods and corals of a likely Early Mississippian age. Apparently, these outcrops currently fall within the mining area and they had been probably destroyed.

The presence of Early Mississippian conodonts at the Estación Sahuaro (Figures 2, 6, loc. C1) and the Cerro La Cal (Figures 2, 6, loc. C11) has been reported by Stewart and Poole (2002) and Poole et al. (2005), respectively.

Deep-water strata. The only locality reported in the literature as containing Early Mississippian fossils in the Sonora allochthon is the Cerro Cobachi (Figures 3, 6, loc. D1). Ketner and Noll (1987) dated part of the Guayacán Group as Kinderhookian-Osagean, although they did indicate neither the fossil group nor association.

Middle Mississippian

Continental shelf. Late Osagean-Meramecian conodonts, especially cavusgnathids and Gnathodus texanus, have been described by Stewart et al. (1999), and Navas-Parejo et al. (in press) from different sections at Sierra Agua Verde (Figures 3, 7, loc. S14), and by Casarrubias (2015) at the Puerto del Orégano (Figures 3, 7, loc. S7). According to Stewart and Poole (2002), late Osagean-Meramecian conodonts also appear in the Rancho Sobechi area (Figures 3, 7, loc. S10). Late Meramecian deposits have been identified also in the El Rancho El Bízani (Figures 2, 7, loc. S1) by means of brachiopods (Cooper and Arellano, 1946) and conodonts (Brunner, 1976).

Other Middle Mississippian fossils described by Peiffer-Rangin (1988) were corals from the Puerto Mátape (Figures 3, 7, loc. S15) and the Cerro Tuntunudé (Figures 3, 7, loc. S16), as well as early Middle Mississippian foraminifera and brachiopods from the Cerro San Pedro (Figures 3, 7, loc. S17). Middle Mississippian corals and brachiopods were also described by Palafox et al. (1984) at the Cerro Peñasco Blanco (Figures 3, 7, loc. S21).

Cratonic platform. In the Sierra de Teras-El Tigre area (Figures 2, 6, loc. C8), Holcomb (1979) and Devery (1979) reported an Osagean to Meramecian conodont fauna from the lowest member defined by Imlay (1939) in the same area. According to the sections described by Peiffer-Rangin (1988) in the Cerros Las Mesteñas, Middle Mississippian is very likely present, although no definite Visean (late Osagean-early Chesterian) fossils have been reported from this locality. In the Sierra El Tule, Palafox (2011) and Buitrón-Sánchez et al. (2012) reported a Visean-Serpukhovian (late Osagean-Chesterian) interval, which contains mostly Amplexizaphrentis cf. A. sp. and syringoporid corals, although their age is inferred by lithological correlations.

Deep-water strata. Bartolini (1988) and Bartolini et al. (1989) reported the presence of a time averaged conodont assemblage in the Sonora allochthon of the Sierra El Aliso, being the youngest conodonts from late Meramecian to early Chesterian (Figures 3, 6, loc. D5).

\section{Upper Mississippian}

Continental shelf. The presence of several Chesterian biozones in continental-shelf strata was demonstrated with conodonts at the Sierra Santa Teresa (Figures 3, 7, loc. S3, Stewart et al. 1997), and at the Sierra Agua Verde (Figures 3, 7, loc. S14, Navas-Parejo et al., in press), where Stewart et al. (1999) also reported Chesterian corals, algae, foraminifera, and incertae sedis.

Chesterian rocks are also reported at the Cerro Cobachi area (Figures 3, 7, loc. S9) by means of corals (Noll, 1981; Ketner and Noll, 1987). In addition, Glomospira sp. and Asteroarchaediscus postrugosus described by Peiffer-Rangin (1988) from the southern flank of the Sierra Santa Teresa may indicate a late Chesterian or Morrowan age.

Cratonic platform. Imlay (1939) reported Carboniferous fossils for the first time in Sonora, a rich but poorly preserved brachiopod fauna from the El Tigre mine area (Figures 2, 6, loc. C8). This association was studied by Arthur Cooper (Cooper in Imlay, 1939) who identified several specimens indicating a Mississippian, very probably, Chesterian age.

Peiffer-Rangin (1988) studied several sections within the Sierra El Tule range and reported Early Mississippian corals and Late Mississippian-Early Pennsylvanian foraminifera and incertae sedis groups.

Deep-water strata. Chesterian to Morrowan radiolarians of the Albaillella-3 assemblage were described by Poole et al. (1983) from the lower part of the Rancho Nuevo Formation at the Barita de Sonora area (Figures 3, 6, loc. D2). Bartolini (1988) and Bartolini et al. (1989) re- 


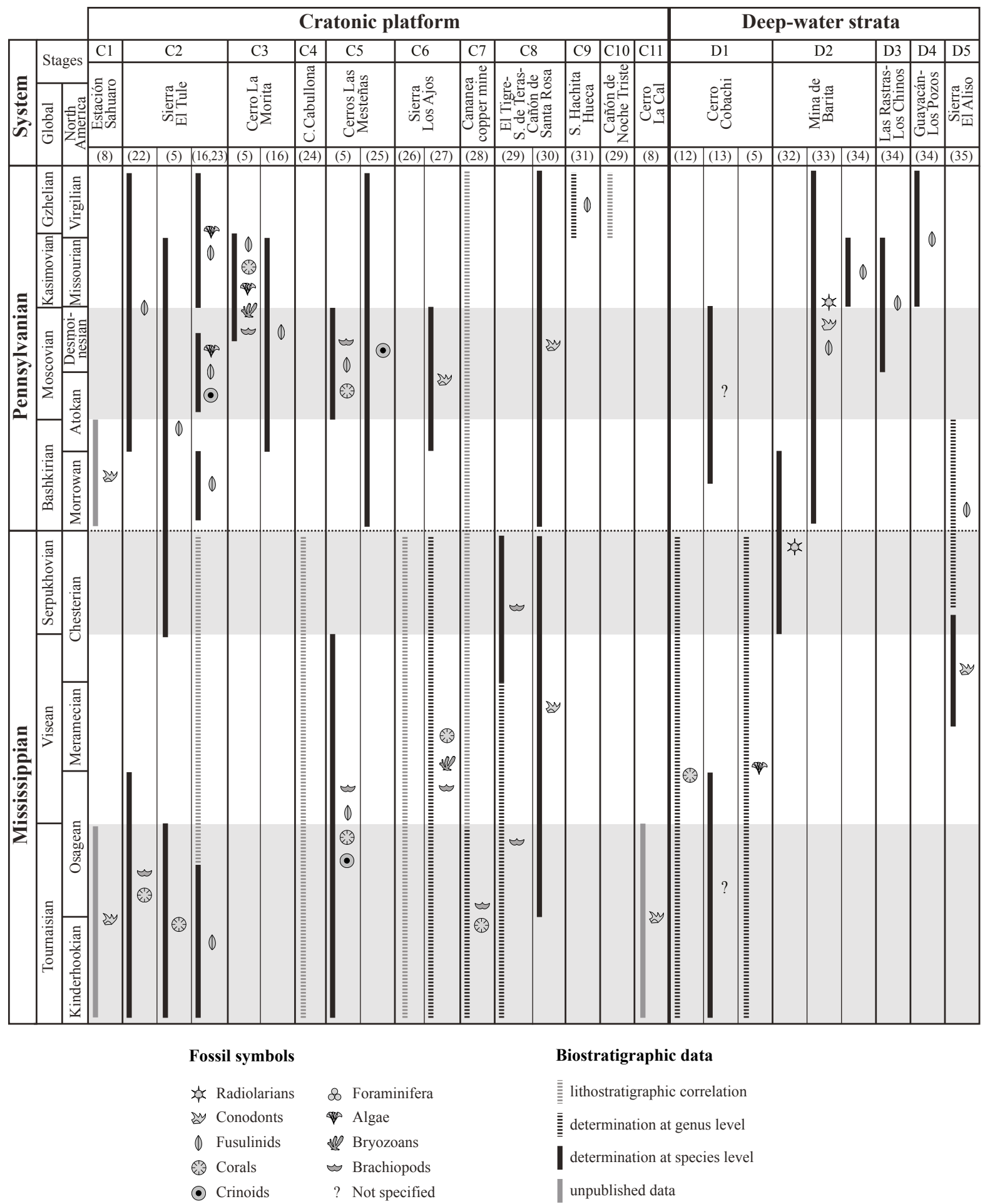

Figure 6. Synthesis of Carboniferous biostratigraphic data for the cratonic platform and deep-water rocks of Sonora. Data were compiled from multiple sources, indicated by numbers in parentheses and listed in Table 1. See position of localities in Figures 2 and 3. S. stands for Sierra; C. stands for Cerro. Fossil symbols after U.S. Geological Survey (2006).

ported Late Mississippian or possibly Early Pennsylvanian foraminifera, without specifying taxa, from the Sierra El Aliso (Figures 3, 6, loc. D5).

\section{Pennsylvanian}

In the continental-shelf strata, Pennsylvanian rocks seem to appear less frequently than the Mississippian, being the Morrowan the stage less commonly present. On the contrary, in the Sonora allochthon, the Pennsylvanian crops out more commonly than the Mississippian. Pennsylvanian fossils of the continental-shelf facies, not studied in detail and not well-constrained biostratigraphically, have been reported from the Sierra Agua Verde (Figures 3, 7, loc. S14) by Ochoa-Granillo and Sosa-León (1993), and from the El Real Viejo (Figures 3, 7, loc. 
S20) by Minjárez et al. (1985). Not detailed reports with Pennsylvanian fossils also include the brachiopod fauna reported by Stewart and Poole (2002) from the Sierra Santo Domingo (Figures 3, 7, loc. S21). In the cratonic platform and the Sonora allochthon, a relatively complete Pennsylvanian succession is present.

The most complete Pennsylvanian record appears in the cratonic strata at the Sierra El Tule (Figures 2, 6, loc. C2). The Upper Pennsylvanian is, apparently, absent in the continental-shelf sequence cropping out in Sonora since distinct Missourian and Virginian fossils have not been yet found there.

Regarding the Sonora allochthon, and according to Poole and Amaya-Martínez (2000), fusulinids, radiolarians and conodonts indicate the presence of all Pennsylvanian stages in the Rancho Nuevo Formation at the Mina de Barita type area (Figures 2, 6, loc. D2).

Reports of Pennsylvanian fossils with or without biostratigraphic implications are listed in Figures 6 and 7.

\section{Lower Pennsylvanian}

Continental shelf. Morrowan and lower Atokan rocks have been accurately dated only in the Sierra Santa Teresa and the Sierra Agua Verde. The earliest Morrowan fossils have been found in the Sierra Agua Verde (Figures 3, 7, loc. S14). Stewart et al. (1999) described calcareous microfossils from the Zone 20 (the first foraminiferal zone of the Pennsylvanian), and Navas-Parejo et al. (in press) found the noduliferus Zone (the first Pennsylvanian biozone) by means of conodonts.

In the Sierra Santa Teresa (Figures 3, 7, loc. S3), Stewart et al. (1997) reported several species of middle to late Morrowan conodonts, and Peiffer-Rangin (1988) found Chaetetes milleporaceous, a number of Pennsylvanian foraminifera, and other fossils without biostratigraphic importance. In the Sierra Agua Verde, Stewart et al. (1999), using foraminifera, algae and incertae sedis, identified all the Lower Pennsylvanian foraminifera zones, from the early Morrowan (Zone 20) up to the late Atokan (Zone 23).

At Cerro Cobachi (Figures 3, 7, loc. S9), Ketner and Noll (1987) reported two samples of late Morrowan and Morrowan-Atokan ages, respectively. They did not include, however, the fossil group or the fossil association.

Cratonic platform. Crinoid associations from the Cerros Las Mesteñas (Figures 2, 6, loc. C5) studied by Villanueva-Olea et al. (2016) contained Pentagonomischus plebeius, indicating a Morrowan to Desmoinesian age. Palafox (2011) and Buitrón-Sánchez et al. (2012) described Morrowan-Atokan fusulinids from the lower part of the section they measured in the Sierra El Tule (Figures 2, 6, loc. C2).

Early Pennsylvanian fauna from the cratonic succession also includes unpublished conodonts reported by Stewart and Poole (2002) at the Estación Sahuaro (Figures 2, 6, loc. C1), and those reported by Holcomb (1979) and Devery (1979) from the Sierra de Teras area (Figures 2, 6, loc. C8).

Deep-water strata. Ketner and Noll (1987) included late Morrowan ages from several samples collected at the Cerro Cobachi (Figures 3, 6, loc. D1), without specifying taxa.

Reports made by Poole et al. (1983) at the Mina de Barita area (Figures 3, 6, loc. D2), and by Bartolini (1988) and Bartolini et al. (1989) in the Sierra El Aliso (Figures 3, 6, loc. D5), already included in the Upper Mississippian section above, also contained possible Early Pennsylvanian radiolarians and foraminifera, respectively.

\section{Middle Pennsylvanian}

Continental shelf. A late Atokan rich fauna association appears in the Sierra Agua Verde (Figures 3, 7, loc. S14). There, fossil associations from different sections within the range, including chaetetids and crinoids (Buitrón-Sánchez et al., 2007; Almazán-Vázquez et al.,
2007), and corals, foraminifera and algae (Stewart et al., 1999), have been profoundly studied.

In the Sierra Santa Teresa (Figures 3, 7, loc. S3), Atokan fusulinids and Atokan-Desmoinesian conodonts (Stewart et al., 1997), as well as Atokan-Desmoinesian corals, fusulinids and foraminifers (PeifferRangin, 1988) have been described.

Pérez-Ramos (1992) found an Atokan fusulinid fauna in a Permian succession at the Ebenezer mine section (Figures 3, 7, loc. S23). She concluded that this fauna should come from a displaced faulted block or they may represent reworked fauna.

Cratonic platform. Late Atokan to Desmoinesian fusulinids are common in the Sierra El Tule area (Figures 2, 6, loc. C2), and have been described by González-León (1986), Peiffer-Rangin (1988), Palafox (2011) and Buitrón-Sánchez et al. (2012). Equivalent fauna was studied by Palafox (2011) at the Cerro La Morita (Figures 2, 6, loc. C3) and by Peiffer-Rangin (1988) at the Cerros Las Mesteñas (Figures 2, 6, loc. C5). Atokan to Desmoinesian conodonts from cratonic-platform strata were described by Page et al. (2010) at the Sierra Los Ajos (Figures 2, 6, loc. C6), and by Holcomb (1979) and Devery (1979) from the Sierra de Teras (Figures 2, 6, loc. C8).

Deep-water strata. Ketner and Noll (1987) collected a sample from the Vuelta Colorada Formation (Cerro Cobachi: Figures 3, 6, loc. D1) that was dated as Atokan to Desmoinesian by Benita L. Murchey (Murchey in Ketner and Noll, 1987).

\section{Upper Pennsylvanian}

Cratonic platform. In the Cerros Las Mesteñas (Figures 2, 6, loc. C5), Peiffer-Rangin (1988) recognized a stratigraphic hiatus that spans the Upper Pennsylvanian and the Permian. Villanueva-Olea et al. (2016), however, described several Missourian and Virgilian crinoids in the same area, being Cyclocaudex jucundus, Cyclocaudiculus regularis, and Cyclocrista cheneyi the most indicative.

Very rich fossil associations indicating early and late Missourian ages were studied by Peiffer-Rangin (1988) from the Cerro La Morita area (Figures 2, 6, loc. C5). These associations include abundant algae, fusulinids, corals, bryozoans and brachiopods. According to Palafox (2011) and Buitrón-Sánchez et al. (2012), distinctive Missourian and Virgilian fusulinids, such as Triticites canyonensis, Triticites acutuloides, Triticites ex gr. beedei, and Leptotriticites ex gr. eoextentus, are present in the Sierra El Tule (Figures 2, 6, loc. C2).

Deep-water strata. Stevens et al. (2014) studied several samples from different localities of the Sonora allochthon (Figures 3, 6, locs. D2, D3, and D4) and reported the presence of Desmoinesian, Missourian and Virgilian fusulinid associations.

\section{CONCLUSIONS}

An exhaustive review of the current knowledge on the Carboniferous biostratigraphy of Sonora reveals the necessity of more detailed paleontological studies. All Mississippian and Pennsylvanian stages are more or less present in the Carboniferous record of the Sonoran Paleozoic. In addition, the geographical proximity of diverse but contemporaneous paleoenvironments, and the continuity of most successions are promising and indicate a high potential of the region for important contributions on different paleontological fields as taxonomy, phylogeny and paleobiogeography of the fossil groups present. Detailed paleontological studies have been made, however, only in a few localities, being conodonts and fusulinids the groups most satisfactorily used for biostratigraphic analysis.

The Sonora allochthon stratigraphic formations defined by Poole and collaborators (e.g., Poole and Madrid 1988, Poole and Amaya- 


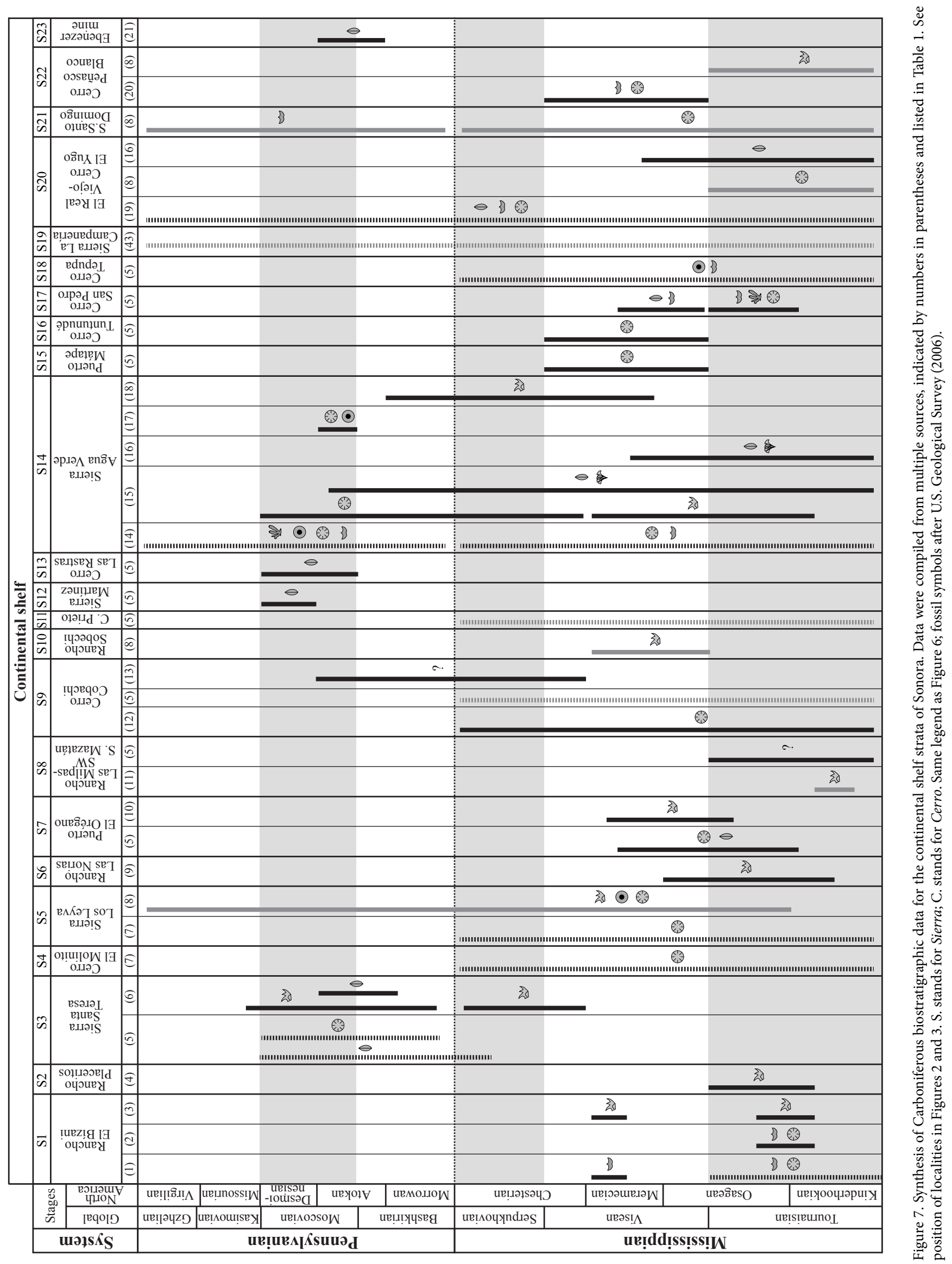


Martínez 2000, Poole et al. 2005, 2008, Stevens et al.2014), correlate and update the formations defined in the Cerro Cobachi area by Noll (1981) and Ketner and Noll (1987). Cratonic-platform successions cropping out in northern Sonora seem to correspond to the southern extension of the equivalent lithostratigraphic units defined in southern United States and the use of that nomenclature is advisable. Lithostratigraphic units in the continental shelf have been defined formally at some localities, but most commonly informally in unpublished theses. Regional studies on these successions are needed in order to propose a realistic and complete stratigraphic chart of the most common Carboniferous rocks cropping out in northwestern Mexico.

The earliest well-constrained Mississippian age reported until now in Sonora is middle Kinderhookian. This dating was found by means of conodonts from the continental-shelf strata in the central part of the state (Figures 3, 7: Rancho Las Norias, loc. S6, and SW Sierra Mazatán, loc. S8). In the cratonic-platform rocks, the earliest Carboniferous age obtained so far is Kinderhookian-Osagean at the Sierra El Tule (Figures 2, 6, loc. C2). In the Sonora allochthon, the lowest Mississippian outcrop reported is also Kinderhookian-Osagean (Figures 3, 6: Cerro Cobachi, loc. D1). The most complete Mississippian record is in the Sierra Agua Verde and the Sierra El Tule.

The earliest and best-constrained Pennsylvanian deposits in Sonora have been reported from the Sierra Agua Verde (Figures 3, 7, loc. S14). Morrowan fossils have been described also from the cratonic-shelf succession (Figures 2, 6: Cerros Las Mesteñas, loc. C5, and Sierra El Tule, loc. C2) and the Sonora allochthon (Figures 3, 6: Cerro Cobachi, loc. D1).

An Upper Pennsylvanian stratigraphic gap in the continental shelf of southern Laurentia is present in Sonora. Other Carboniferous successions currently cropping out in Sonora seem to show a relatively continuous record, although local hiatuses and gaps do exist. Most Carboniferous fossils found in Sonora have not been properly studied and/or made part of unpublished studies. Therefore, detailed paleontological and biostratigraphic studies in most of the localities are also needed in order to better constrain the presence of regional disconformities.

\section{ACKNOWLEDGEMENTS}

I acknowledge Francisco Sour Tovar and Miguel Torres Martínez for reviewing the manuscript as well as editor Ricardo Barragán Manzo. Maps were created using free software QGIS and shape layers downloaded from CONABIO, INEGI and SGM websites (Federal Mexican government). Financial support provided by UNAM-DGAPA-PAPIIT project IA104217.

\section{REFERENCES}

Almazán-Vázquez, E., Buitrón-Sánchez, B.E., Vachard, D., Mendoza-Madera, C., Gómez-Espinosa, C., 2007, The late Atokan (Moscovian, Pennsylvanian) chaetetid accumulations of Sierra Agua Verde, Sonora (NW Mexico): composition, facies and palaeoenvironmental signals, in Álvaro, J.J., Aretz, M., Boulvain, F., Munnecke, A., Vachard, D., Vennin, E. (eds.), Palaeozoic Reefs and bioacumulations: Climatic and Evolutionary Controls: Geological Society, London, Special Publications, 275, 189-200.

Álvarez, M., Jr., 1949, Notas sobre el Paleozoico Mexicano: Asociación Mexicana Geólogos Petróleos, 1(1), 47-56.

Aponte-Barrera, M., 1974, Estratigrafía del Paleozoico (Cámbrico-Pensilvánico) del centro de Sonora: México D. F., México, Instituto Politécnico Nacional, Bachelor's Thesis, 67 pp.

Ausich, W.I. 1997. Regional encrinites: a vanished lithofacies, in Brett, C.E.,
Baird, G.C. (eds.) Paleontological Events, Stratigraphic, Ecological and Evolutionary Implications: Columbia University Press, New York, 509-520.

Avila, R., 1987, Consideraciónes geológicas y estratigrafícas de la porción NW de Hermosillo: Hermosillo, México, Universidad de Sonora, Bachelor's Thesis, $78 \mathrm{pp}$.

Bartolini, C., 1988, Regional structure and stratigraphy of Sierra El Aliso, central Sonora, Mexico: Tucson, U.S.A., The University of Arizona, M.Sc. Thesis, $189 \mathrm{pp}$.

Bartolini, C., Stewart, J. H., Carter, C., Murchey, B. L., Repetski, J. E., 1989, Stratigraphy of Paleozoic eugeoclinal strata in Sierra el Aliso, central Sonora, Mexico: Boletín del Departamento de Geología, Universidad de Sonora, 1-2, 11-21.

Blodgett, R. B., Page, W. R., Gray, F., 2002, Paleontologic investigations of the Paleozoic rocks in the Sierra Los Ajos, northern Sonora, Mexico (resumen): Geological Society of America, Abstracts with Programs, 34 (5), 40.

Boucot, A.J., Poole, F.G., Amaya-Martínez, R., Harris, A.G., Sandberg, C.A., Page, W.R., 2008, Devonian brachiopods of southwesternmost Laurentia: Biogeographic affinities and tectonic significance, in Blodgett, B.R., Stanley, G.D. Jr (eds.), The terrane puzzle: New perspectives on paleontology and stratigraphy from the North American Cordillera: Boulder, Geological Society of America Special Paper, 442, 77-97.

Bridges, L.W., 1970, Paleozoic history of the southern Chihuahua tectonic belt, in Seewald, K., Sundeen, D. (eds.), The geologic framework of the Chihuahua tectonic belt: Midland, West Texas Geological Society, 67-74.

Brunner, P, 1976, Litología y Bioestratigrafía del Misisipico en el área de El Bisani, Caborca, Sonora: Revista del Instituto Mexicano del Petróleo, $8,7-41$.

Buitrón-Sánchez, B.E., Gómez-Espinosa, C., Almazán-Vázquez, E., Vachard, D., 2007, A late Atokan regional encrinite (early late Moscovian, Middle Pennsylvanian) in the Sierra Agua Verde, Sonora state, NW Mexico, in Álvaro, J.J., Aretz, M., Boulvain, F., Munnecke, A., Vachard, D., Vennin, E. (eds.), Palaeozoic Reefs and bioacumulations: Climatic and Evolutionary Controls: Geological Society, London, Special Publications, 275, 201-209.

Buitrón-Sánchez, B.E., Vachard, D., Almazán-Vázquez, E., Palafox, J.J., 2012, Una secuencia cratónica del Carbonífero al Pérmico inferior expuesta en los cerros El Tule, noreste de Sonora, México: Revista Mexicana de Ciencias Geológicas, 29(1), 39-62.

Casarrubias, A., 2015, Bioestratigrafía de conodontos del Paleozoico superior del área del Puerto del Orégano (Sonora central): Hermosillo, México, Universidad de Sonora, Bachelor's Thesis, $53 \mathrm{pp}$.

Cocks, L.R.M., Torsvik, T.H., 2011, The Paleozoic geography of Laurentia and western Laurussia: A stable craton with mobile margins: Earth-Science Reviews, 106, 1-51.

Cooper, G.A., Arellano, A.R.V., 1946, Stratigraphy near Caborca, northwest Sonora, Mexico: American Association of Petroleum Geologists Bulletin, 40 (4), 606-619.

Devery, J.P., 1979, Sedimentary petrology of the upper Paleozoic carbonates near Bavispe, Sonora, Mexico: Fort Worth, U.S.A., Texas Christian University, M.Sc. Thesis, 79 pp.

Dunbar, C.O, 1939, Permian fusulinids from Sonora: Bulletin of the Geological Society of America, 50, 1745-1760.

Easton, W.H., Sanders, J.E., Knight, J.B., Miller, A.K., 1958, Mississippian fauna in northwestern Sonora, Mexico: Smithsonian Miscellaneous Collections, 119 (3), 1-87.

Gastil, R.G., 1993, Prebatholithic history of peninsular California, in Gastil, R.G., Miller, R.H., (eds.), The Prebatholithic Stratigraphy of Peninsular California: Boulder, Geological Society of America Special Paper, 279, 145-156.

Gómez-Tagle, A., 1967, Estudio geológico de la Sierra de las Mesteñas, municipio de Fronteras, Estado de Sonora: México D.F., México, Universidad Nacional Autónoma de México, Bachelor's Thesis, 69 pp.

González-León, C., 1986, Estratigrafía del Paleozoico de la Sierra del Tule, noreste de Sonora: Revista del Instituto de Geología, Universidad Nacional Autónoma De México, 6, 117-135.

González-León, C., Valencia-Moreno, M., Noguéz Alcantara, B., Salvatierra Domínguez, E., 2006, Mapa Geológico de Sonora, México, escala 1:1,000,000: Digital Geosciences.

Gutschick, R.C., Sandberg, C.A., 1983, Mississippian continental margins of the conterminous United States. Society for Sedimentary Geology Special 
Publication, 33, 79-96

Hewett, R.L., 1978, Geology of the Cerro La Zacatera area, Sonora, Mexico: Flagstaff, U.S.A., Northern Arizona University, M.Sc. Thesis, 99 pp.

Holcomb, R.A., 1979, Conodont biostratigraphy of the Paleozoic carbonates near Bavispe, Sonora, Mexico: Fort Worth, U.S.A., Texas Christian University, M.Sc. Thesis, 99 pp.

Imlay, R.W., 1939, Paleogeographic studies in northeastern Sonora: Geological Society of America Bulletin, 50 (11), 1723-1744.

Ketner, K.B., Noll, J.H., Jr., 1987, Preliminary geologic map of the Cerro Cobachi area, Sonora, Mexico: U.S. Geological Survey Miscellaneous Field Studies Map MF-1980, scale 1:20,000.

López-Ramos, E., 1982, Geología de México, Tomo II (tercera edición): México, D.F., Tesis Resendiz S.A., 454 pp.

Minjárez, J., Torres, Y., 1987, Geologia del area de Bacanora-Arivechi. Hacia un esquema de Evolucion Geologica Jurasico-Cretacico, Sonora: Hermosillo, México, Universidad de Sonora, Bachelor's Thesis, 85 pp.

Minjárez, I., Palafox, J.J., Torres, Y., Martínez, J.A., Rodríguez, B., Villalobos, R., 1985, Consideraciones respecto a la estratigrafía y estructura del área de Sahuaripa-Arivechi: Boletín Segunda Época, Departamento de Geología Universidad de Sonora, 2, 90-105.

Mulchay, R.B., Velasco, J.B., 1954. Tentative correlation of the sedimentary rocks at Cananea, Sonora, Mexico with the section at Bisbee, Arizona: American Institute of Mining and Metallurgical Engineers Transactions, 199, $11 \mathrm{pp}$.

Navas-Parejo, P., Sandberg, C.A., Poole, F.G. 2016a. New evidence from Sonora for close approach of Gondwana to Laurentia in Late Devonian (resumen): Geological Society of America, Abstract with Programs, 48(7), Paper No. 347-34.

Navas-Parejo, P., Sandberg, C.A., Poole, F.G. 2016b. Paleogeographic significance of Late Devonian (early Famennian) offshore-marine conodont Palmatolepis crepida (resumen): Geological Society of America Abstract with Programs, 48(7), Paper No. 45-6.

Navas-Parejo, P., Lara-Peña, R.A., Torres-Martínez, M.A., Martini, M., 2018, Biostratigraphy and petrography of upper Paleozoic rocks of Sierra Las Pintas, northern Baja California: Journal of South American Earth Sciences, DOI: 10.1016/j.jsames.2018.03.010.

Navas-Parejo, P., Palafox, J. J., Villanueva, R., Buitrón-Sánchez, B. E., ValenciaMoreno, M., in press, Mid-Carboniferous shallow-water conodonts from NW Mexico: Micropaleontology.

Noll, J.H., Jr., 1981, Geology of the Picacho Colorado area, northern Sierra de Cobachi, central Sonora, Mexico: Flagstaff, U.S.A., Northern Arizona University, M.Sc. Thesis, $165 \mathrm{pp}$.

Noll, J.H., Dutro, J.T., Jr., Beus, S.S., 1984, A new species of the Late Devonian (Famennian) brachiopod Dzieduszyckia from Sonora, Mexico: Journal of Paleontology, 58(6), 1412-1421.

Ochoa-Granillo, J.A., Sosa-León, J.P., 1993, Geología y estratigrafía de la Sierra Agua Verde con énfasis en el Paleozoico: Hermosillo, México, Universidad de Sonora, Bachelor's Thesis, 59 pp.

Page, W.R., Harris, A.G., Poole, F.G., Repetski, J.E., 2003, Reinterpretation of the stratigraphy and structure of the Rancho Las Norias area, central Sonora, Mexico: Journal of South American Earth Sciences, 16, 523-540.

Page, W.R., Gray, F., Iriondo, A., Miggins, D., Blodgett, R.B., Maldonado, F., Miller, R.J., 2010, Stratigraphy and Mesozoic-Cenozoic tectonic history of northern Sierra Los Ajos and adjacent areas, Sonora, Mexico: Journal of South American Earth Sciences, 29, 557-571.

Palafox, J.J., 2011, Du craton au Rheïque: le nord et le centre de l'etat du Sonora (Mexique) au Paleozoïque superieur (Devonien-Pennsylvanien), Lithostratigraphie, Biostratigraphie, approche geochimique et implications geologiques: Villeneuve d'Ascq, France, Université de Lille1, Ph.D. Thesis, 315 pp.

Palafox, J.J., Martínez, J.A., 1985, Estratigrafía del área de Arivechi, Sonora. Boletín del Departamento de Geología, Universidad de Sonora, 2, 30-59.

Palafox, J.J., Minjárez, J.I., Pubellier, M., Rascon, B., 1984, Sobre la presencia de rocas del Paleozoico superior en el área de Arivechi, Sonora, México: Boletín del Departamento de Geología, Universidad de Sonora, 1(1), 60-62.

Pantoja-Alor, A.J., 1970, Rocas sedimentarias paleozoicas de la región centro septentrional de Oaxaca: Sociedad Geológica Mexicana, Libreto Guía de la Excursión México-Oaxaca, 67-84.

Peiffer-Rangin, F., 1979, Les zones isopiques du Paléozoïque inférieur du nordouest mexicain, témoins du relais entre les Appalaches et la cordillère ouest-américaine: Comptes Rendus de l'Académie des Sciences Paris, Série D, 288, 1517-1519.

Peiffer-Rangin, F., 1988, Biostratigraphic study of Paleozoic rocks of northeastern and central Sonora: Unpublished manuscript on file with F.G. Poole, U.S. Geological Survey, Denver, Colorado,, 90 pp.

Pérez-Ramos, O., 1992, Permian biostratigraphy and correlation between southeast Arizona and Sonora: Boletín del Departamento de Geología, Universidad de Sonora, 9, 1-74.

Poole, F.G., Amaya-Martínez, R., 2000, The Sonora orogen in the Barita de Sonora Mine area east of Mazatán, Central Sonora, in Guide to Field Trip 3 for the Fourth Symposium on the Geology of northwest Mexico and adjacent areas, Universidad de Sonora, Hermosillo, Mexico, 1-27.

Poole, F.G., Madrid, R.J., 1988, Comparison of allochthonous Paleozoic eugeoclinal rocks in the Sonoran, Marathon, and Antler orogens (resumen): Geological Society of America, Abstracts with Programs, 20 (7), 267.

Poole, F.G., Sandberg, C.A., 1977, Mississippian paleogeography and tectonics of the western United States, in Stewart, J.H., Stevens, C.H., Fritsche, A.E. (eds.), Pacific Coast Paleogeography Symposium 1: Los Angeles, Society of Economic Paleontologists and Mineralogists, 67-85.

Poole, F.G., Muchey, B.L., Stewart, J.H., 1983, Bedded barite of middle and late Paleozoic age in central Sonora, Mexico (resumen): Geological Society of America, Abstracts with Programs, 15(5), 299.

Poole, F.G., Amaya-Martínez, R., Harris, A.G., 2003, Early Mississippian North American carbonate-shelf margin in west-central Sonora, Mexico: Geological Society of America, Abstracts with Programs, 35(4), 14.

Poole, F.G., Perry, W.J., Jr, Madrid, R.J., Amaya-Martínez, R., 2005, Tectonic synthesis of the Ouachita-Marathon-Sonora orogenic margin of southern Laurentia: Stratigraphic and structural implications for timing of deformational events and plate-tectonic model, in Anderson, T.H., Nourse, J.A. Mckee, J.W., Steiner, M.B. (eds.), The Mojave-Sonora megashear hypothesis: Development, assessment, and alternatives: Boulder, Geological Society of America Special Paper, 393, 543-596.

Poole, F.G., Gehrels, G.E., Stewart, J.H., 2008, Significance of detrital zircons in Upper Devonian ocean-basin strata of the Sonora allochthon and Lower Permian synorogenic strata of the Mina México foredeep, central Sonora, México, in Blodgett, R.B., Stanley, G.D., Jr (eds.), The terrane puzzle: New perspectives on paleontology and stratigraphy from the North American Cordillera: Boulder, Geological Society of America Special Paper, 442, 121-131.

Ransome, F.L., 1904, The Geology and ore deposits of the Bisbee quadrangle, Arizona: United States Geological Survey, Professional Paper, 21, 1-168.

Reyes-Montoya, D., 2017, Bioestratigrafía del Cámbrico-Ordovícico de Sonora central: Implicaciones paleogeográficas y paleoecológicas): Hermosillo, México, Universidad de Sonora, M.Sc. Thesis, $112 \mathrm{pp}$.

Rodríguez-Castañeda, J.L., 1981, Notas sobre la geología del área de Hermosillo, Sonora: Revista del Instituto de Geología, Universidad Nacional Autónoma De México, 5, 30-36.

Sánchez-Zavala, J.L., Centeno-García, E., Ortega-Gutiérrez, F., 1999, Review of Paleozoic stratigraphy of Mexico and its role in the Gondwana-Laurentia connections, in Ramos, V.A., Keppie, J.D. (eds.), Laurentia-Gondwana connections before Pangea: Boulder, Geological Society of America Special Paper, 336, 211-225.

Schmidt, G.T., 1978, Geology of the northern Sierra El Encinals, Sonora, Mexico: Flagstaff, U.S.A., Northern Arizona University, M.Sc. Thesis, 80 pp.

Stevens, C.H., Poole, F.G., Amaya-Martínez, R., 2014, Late Paleozoic fusulinids from Sonora, México: Importance for interpretation of depositional settings, biogeography, and paleotectonics: Revista Mexicana de Ciencias Geológicas, 31(1), 14-27.

Stewart, J.H., 1988, Latest Proterozoic and Paleozoic southern margin of North America and the accretion of Mexico: Geology, 16, 186-189.

Stewart, J.H., Poole, F.G., 2002, Inventory of Neoproterozoic and Paleozoic strata in Sonora, Mexico. United States Geological Survey Open-File Report, 02-97, 1-50.

Stewart, J.H., Poole, F.G., Ketner, K.B., Madrid, R.J., Roldán-Quintana, J., Amaya-Martínez, R., 1990, Tectonics and Stratigraphy of the Paleozoic and Triassic southern margin of North America, Sonora, Mexico, in Gehrels, G.E., Spencer, J.E. (eds.), Geologic excursions through the Sonoran Desert Region, Arizona and Sonora: Arizona Geological Survey Special Paper, 7, 183-202. 
Stewart, J.H., Amaya-Martínez, R., Stamm, R.G., Wardlaw, B.R., Stanley, G.D., Jr, Stevens, C.H., 1997, Stratigraphy and regional significance of Mississippian to Jurassic rocks in Sierra Santa Teresa, Sonora, Mexico: Revista Mexicana de Ciencias Geológicas, 14(2), 115-135.

Stewart, J. H., Poole, F. G., Harris, A. G., Repetski, J. E., Wardlaw, B. R., Mamet, B., Morales-Ramírez, J. M., 1999, Neoproterozoic(?) to Pennsylvanian inner-shelf, miogeoclinal strata in Sierra Agua Verde, Sonora, Mexico: Revista Mexicana de Ciencias Geológicas, 16(1), 35-62.

Taliaferro, N.L., 1933, An occurrence of Upper Cretaceous sediments in northern Sonora, Mexico: Journal of Geology, 41(1), 12-37.

U.S. Geological Survey, 2006, FGDC Digital Cartographic Standard for Geologic Map Symbolization (PostScript Implementation): U.S. Geological Survey Techniques and Methods 11-A2 <http://pubs.usgs.gov/tm/2006/11A02/>.

Vega-Granillo, R., 1996, La sierra de Mazatán, Sonora, México: Geología y análisis estructural de un complejo metamórfico en la parte sur de la provincia de "Basin and Range": Hermosillo, Mexico, Universidad de Sonora, M. Sc. Thesis, $128 \mathrm{pp}$.

Vega-Granillo, R., Araux, E., 1985, Estudio geológico de la Sierra La Campanería y sus yacimientos minerales: Boletín del Departamento de Geología, Universidad de Sonora, 2 (1-2), 74-84.
Vega-Granillo, R., Araux, E., 1987, Estratigrafía del Paleozoico en el área del Rancho Las Norias, Sonora Central: Boletín del Departamento de Geología, Universidad de Sonora, 4 (1- 2), 41-50.

Villanueva-Olea, R., Buitrón-Sánchez, B.E., Palafox-Reyes, J.J., Piña-Flores, S., 2016, Crinoides (Echinodermata: Crinoidea) del Pensilvánico de sierra Las Mesteñas, NE Sonora, México: Revista Mexicana de Biodiversidad, 87, 1225-1234.

Viveros-Martínez, A., 1965, Estudio geológico de la Sierra de Cabullona, Municipio de Agua Prieta, Estado de Sonora: México D.F., México, Universidad Nacional Autónoma de México, Bachelor’s Thesis, 82 pp.

Manuscript received: november 28, 2017

Corrected manuscript received: january 29, 2018

Manuscript accepted: february 6, 2018 